\title{
Identifying Existing Positive Disharmonies for Reconstructing Teaching Practice: A Case Study in
} Japan

\author{
Fumi Takegami ${ }^{1, *}$ \\ ${ }^{1}$ Faculty of Letters, Department of English Language and Literature, Prefectural University of \\ Kumamoto, Kumamoto, 862-8502, Japan \\ *Corresponding author: Faculty of Letters, Department of English Language and Literature, \\ Prefectural University of Kumamoto, 3-1-100, Tsukide, Higashi-ku, Kumamoto, 862-8502, \\ Japan. Tel: 81-96-383-2929. E-mail: takegami@pu-kumamoto.ac.jp
}

Received: April 20, $2020 \quad$ Accepted: May 6, 2020 Published: May 22, 2020

doi:10.5296/ije.v12i2.16885 URL: https://doi.org/10.5296/ije.v12i2.16885

\begin{abstract}
The purpose of this paper is to report outcomes of the study regarding the professional development of a Japanese teacher of English (JTE) helping her to meet the recent national English foreign language curriculum policy in Japan. The policy requires teachers to basically conduct classes in English. An action research framework was used. The participant, in collaboration with the author, went through praxis-oriented cycles built on planning, doing reflecting and revising. Data were collected and analyzed using grounded theory methods. A three-stage coding process led to the emergence of two core themes to encapsulate the data: Existing Positive Disharmonies (EPD), a disruptive zone leading to possibility of change; and Reconstructing Teaching Practice (RTP), in which the participant experienced changes that worked in her lessons. This led to the advancement in her teacher development to meet the demands of the new curriculum policy. The paper demonstrates that shedding light on positive disharmonies within teaching practices was useful in the participant's professional development helping her to make instructional adjustments required by policy changes. It is plausible that the outcomes of this study may be transferable to teachers working in other similar teaching environments. Accordingly, a model for teacher development is presented to help JTEs and other teachers in their teacher development.
\end{abstract}

Keywords: case study, grounded theory methods, JTE, positive disharmony, reconstructing teaching practice, teacher cognition, teacher development 


\section{Introduction}

In Japan, the recent teach English through English (TETE) policy of The Ministry of Education, Science and Sports Culture (hereafter referred to as MEXT) for secondary high school Japanese teachers of English (JTEs) has been controversial. The TETE policy is an addendum to an English curriculum goal that has existed for over 30 years prioritizing development of students' communicative abilities to convey information, and ideas etc.; however, it is apparent that the long-held English curriculum goal has not been satisfactorily met. The recent TETE policy suggests a doubling down by MEXT (2009) to further push JTEs along the spectrum toward more active English use for communicative purposes. The policy requires JTEs to basically conduct their classes in English, by implementing more interactive, student-centered lessons.

There have been myriad reactions to the TETE policy. Igawa (2013) argued that the policy comes as a shock to JTEs, who mostly teach in Japanese from the textbook, using grammar translation in a teacher-centered environment, where learners are passive. Accordingly, the shock has been intensified because there is a lack of professional development aimed at helping JTEs meet the policy demands requiring a more communicative-based, student-centered classroom environment with social interaction-type learning activities mediated in English (Tahira, 2012). The TETE policy represents a difficult challenge for teacher educators in Japan (Tsukamoto \& Tsujioka, 2013) as they try to narrow the gap between expectations of policy planners at the institutional level and what teachers are prepared to implement at the classroom level. Nonetheless, narrowing this chasm is where teacher development must play a role. This paper focuses on the case study of a high school JTE's developmental process to reconstruct her teaching practices to meet the TETE policy. Getting the participant to reconceptualize her instruction was robustly informed by the field of teacher cognition and the social nature of collaboration in teacher development.

\section{Literature Review}

The field of teacher cognition emerged around the same time researchers were becoming disillusioned with controlled method comparison studies that set out to find a standardized 'best' language teaching method. Disillusionment emerged because the frameworks used in the comparison studies could not reliably depict whether teachers in the treatment groups were purely implementing a prescribed teaching method or if they were naturally including their own personal theories of teaching to address local issues that emerged in their classrooms (Kumaravadivelu, 2006). As Allen, Frolich and Spada (1984) remarked, it is unrealistic to expect implementation of standardized teaching methods because "teachers will tend to implement a particular approach to L2 instruction within the context of their own personal views as to how they think languages are learned best in the classroom" (p.149).

The failure of best method comparison studies that sought a standardize approach to teaching led to a new paradigm in classroom research. One that began to focus on the teacher. As Allwright later wrote, 
$[\mathrm{T}]$ he time was ripe for an alternative approach ... that would no longer see the language teaching world in terms of major rival 'methods' and one that would be more respectful of the complexities of the language teacher's task $(1988$, p. 10).

In mainstream education, the complexities that surround the job of the teacher were recognized when research on teacher cognition began to largely take hold in the mid 1980s. Clark and Peterson's (1986) study is a forerunner of research recognizing the significance of teacher cognition. In their study surveying over 70 studies on teacher thinking at the time, they looked at cognitive processes involved in teacher decision making (e.g., planning decisions before and after teaching, interactive decisions during teaching, and teachers' beliefs and personal theories that influence decision making). Their noteworthy claim was that classroom-based research needs to go beyond the domain of behavioral observation studies cataloging teacher actions to depict what they do, to also include a cognitive domain, emphasizing the teacher's thought processes to better learn why they do what they do. Clark and Peterson posited that the two domains are reciprocal as 'teachers' actions are largely caused by teachers' thought processes, which then in turn affect teachers' actions" (p.258). In language education, studies on teacher cognition began to surface a decade later in the 1990's (e.g., Burns, 1992; Freeman, 1996; Woods, 1996).

Borg (2003) provided a comprehensive review of the emergence of language teacher cognition research listing a multitude of studies, which culminated in his definition of the concept as "the unobservable cognitive dimension of teaching - what teachers know, believe, and think" (p.81). The field of language teacher cognition has continued to develop to go beyond the psychological cognitive domain to include a social dimension (Kubanyiova \& Feryok, 2015). That is, to better understand what goes on in classrooms, the social and contextual realities that influence teachers and learners need to be examined. The 'social' premise coheres with ideas associated with Vygotsky's social cultural theory that social interaction leads development. The social nature of learning also supports Johnson's claim that teacher research has taken a sociocultural turn (2006). Thus, a more comprehensive view of teacher cognition places research in the sociocultural context of classroom settings. In "the contexts of participation in practice" (Kubanyiova \& Feryok, p.43), researchers are better able to understand the teachers' thoughts behind their actions.

Moreover, the inclusion of the social dimension in teacher learning requires the involvement of teachers in on-site teacher development. Professional discourse is further developed through reflective inquiry that emerges through collaboration. In collaborative teacher development, the reflective process through dialog provides cognitive stimulation for teachers to reconceptualize their practice. Reflective inquiry is essential in a teacher's professional developmental journey (Farrell, 2015). Thus, a valuable role of dialogic reflection is that it enriches professional discourse of teachers. When teachers articulate why they are doing what they are doing during reflection, they rethink their practice, which is significant in teacher development (Freeman, 1996). Outcomes of this study will be shown to support this view. 


\subsection{Research Questions}

The study was conducted for the purposes of assisting a JTE to reconstruct her instruction to meet the TETE national curriculum English policy within the context of the classroom. Therefore, the study was classroom based and situated within an action research framework (Burns, 1999; Wallace, 1998). The research questions are as follows:

1. What are the participant's perceptions and practices toward the TETE policy in terms of implementation?

2. Why does the participant do what she does in her instruction?

3. How can outcomes of this study be used to improve teacher development to meet the TETE policy?

\section{Objectives of the Study}

The above questions provided a context for the research. The first two questions underpinned objectives to link the participant's thought processes regarding the TETE policy to her actions in the classroom, respectively. Outcomes from the two questions were addressed in the third question with the objective to inform the teacher development of the participant to help her meet the TETE policy and, if applicable, to better enlighten other teachers who are faced with similar situations outside of this study.

\subsection{Hypothesis}

The study took the position that for teacher development to be effective, it must recognize the participant's thought processes as they occurred within the social and practical contexts of the classroom. Thus, the collaborative, on-site, teacher development framework used in this study focusing on teacher cognition could shed light on why the participant did what she did in her instruction leading to positive outcomes of meeting the TETE policy

\section{Method}

A qualitative approach was taken because of the exploratory and interpretive nature of the study embedded within the social context of the classroom (Bogdan, \& Biklen, 1998). Case study was used so that in-depth analysis of the participant could be carried out. Procedures complementary to a qualitative approach associated with grounded theory (Glaser \& Strauss, 1967; Strauss \& Corbin; 1998) were used to collect and analyze the data in a bottom up manner. For example, 1) gaining emic perspectives of the participant were prioritized as opposed to using a priori categories that would predetermine outcomes; 2) data were coded, analyzed and transcribed through a three-stage iterative coding process (see Figure 1. below).

\subsection{Participant and Setting}

The participant was a high school JTE with four years of experience. The participant is 
referred to as Masako to protect her privacy. She worked in a private school located in northern Japan. Masako expressed an interest to participate in the study with the author, who played a participatory role in the study. Having more than 30 years of teaching experiences in senior high school, the author was a more knowledgeable other (MKO) in Vygotskian terms, and therefore someone with capabilities to fulfill a mentoring role (1933/1978). The project was privately agreed upon and was not institutionally held although the principal was informed and readily approved.

The class size of the target class was 32 second-grade students. The average proficiency level of English varied from grade 3 to grade 2 in English Aptitude test in Japan (EIKEN). Students' motivation of learning English varied. Masako mentioned, "Some want to learn to speak English and some believe that they have an 'aptitude for science' and were not oriented for achievement since they do not like studying English or are not good at learning English".

\subsection{Data Collection and Analysis}

The data collection and analysis were carried out through an action research (AR) cyclical process of planning, doing, observing, reflecting, and finally revising for the subsequent cycles (see Appendix 1). There were five AR cycles and each included: 1) setting lesson goals (informed by professional knowledge introduced by the author); 2) a planning stage; 3) conducting a lesson and observing and recording the lesson; and 4) a stimulated recall post-lesson session stage. In stimulated recall sessions, reconceptualizations of teaching occurred through having Masako watch video recordings of her instruction, which led to revisions of the lesson.

The researcher collaborated with Masako to co-construct the lessons in each cycle during the studying, planning and post session stages where teaching ideas and advice were given (see Appendix 2). The lesson planning stages of AR were built on a praxis model of integrating professional knowledge (theory and methods) with practice (in action) to form lessons. In the theory integration stage interventions emerged (see Appendix 3) as they evolved in this study. The author and Masako had discussions about teaching and learning outlining principles of social constructivism and its complementary teaching methods that are found in communicative language teaching approaches and collaborative learning. These areas of professional knowledge were selected by the author because of their interactive learning principles, which were aligned with the TETE policy. In this paper, informative excerpts from mostly the initial and final cycles are depicted to show Masako's development. (see Appendices for progression of all developmental cycles).

Data collection and analysis occurred throughout the praxis cycles from interviews (INT); observation field notes (OFN) that described what occurred during each research lesson; and stimulated recall (SR) sessions of post-lesson conversations with Masako while watching the video of each research lesson. Collection and analysis of the data were labeled as above and numbered chronologically.

Techniques associated with grounded theory were used to code the data in three stages as shown in Figure 1. Coding was conducted by using Excel software. Open coding was first 
carried out to immediately code incoming data into concepts and mark them accordingly. Next, through an iteration process of comparative analysis (Bogdan \& Biklen, 1998), axial coding was done to identify relationships among concepts to form subcategories that earned their way into the study through substantiation of data (Glaser \& Strauss, 1967). Finally, selective coding eventually led to forming two, larger, core themes (Strauss \& Corbin, 1998). The two core themes are presented in the analysis with support from the subcategories.

\begin{tabular}{|c|c|c|c|c|}
\hline $\begin{array}{c}\text { Open coding } \\
\text { (Initial labeling of } \\
\text { data into concepts) }\end{array}$ & $\vec{b}$ & $\begin{array}{c}\text { Axial coding } \\
\text { (Finding relationships } \\
\text { among concepts) }\end{array}$ & $\Rightarrow$ & $\begin{array}{c}\text { Selective coding } \\
\text { (Forming two major core } \\
\text { themes) }\end{array}$ \\
\hline
\end{tabular}

Figure 1. Three Stage Coding Process using Comparative Analysis

\subsection{Thematic Categories}

Two core themes emerged: Existing Positive Disharmonies (EPD) and Reconstructing Teaching Practice (RTP). The themes reflected articulations and actions of Masako's instruction that led to rethinking her practice, and, in turn, impacted her teacher development.

\subsubsection{Existing Positive Disharmonies (EPD)}

The EPD category brought together a juxtaposition of data that depicted a major conflict in Masako's teacher development between being in a static, non-growth zone and wanting to break out of it to rethink her instruction and to make changes in it. Although the concept of harmony is often considered to be positive and conjures feelings of pleasantness, its use in this category was different. Harmony was viewed as a state of complacency, a safety zone to resist the surrounding conflicting forces of friction. Data showed how Masako avoided attempts at meeting the TETE challenges and making progress in her teacher development, which led to her carrying out duties in a non-reflective manner. Consequently, her teaching was largely reduced to fixed teaching behaviors and routines mostly using grammar translation.

On the other hand, there are factors that can create momentum to push the teachers out of their comfort zone, which would begin the process of gravitating toward productive change if situations are too static. Through destabilization, an impetus for change to evolve from a harmonious static state occurs. Woods wrote (1996), "An important function of research, or new teachers, or new systems of teaching, is to create disharmony, and thus a movement forward" (p. 292). He also concluded that breaking teachers out of their comfort zones was effective in teacher development and that an aim of developers should be "to encourage productive disharmonies" (p. 292). Through collaborating closely with Masako, she began to show signs of being in a destabilizing state, of wanting to break out of her harmonious comfort zone and reconstruct her teaching. 


\subsubsection{Reconstructing Teaching Practice (RTP)}

Through the collaborative process of praxis with the author, in which Masako co-constructed, reflected on and revised her lessons, a professional discourse about her teaching emerged; and she began to reconceptualize her instruction. Freeman (1996) posited that if teachers can articulate their practice through professional discourse informed by theory and reflection, then it might move teachers to reconstruct their teaching and therefore make changes in action. Moreover, Freeman argued that teachers need to experience professional discourse in practice for teacher development to take place. Guskey (2002) further added that teacher change occurs when teachers observe successful results of suggested ideas about teaching (such as those suggested in workshops or in the literature) that work in practice. Consequently, Masako was given chances to see conceptualizations of her lessons carried out in practice.

\section{A Case Study of Masako}

The two core themes as depicted above were used to interpret the teaching practices of Masako. Next, substantiations of these themes are presented.

\subsection{Existing Positive Disharmony (EPD)}

To show the conflicting forces at play in the teacher thinking and instruction of Masako, first, data will show why she was in a static, no-growth state in her teacher development. Then, it will be shown why Masako was conflicted and how it led to an impetus for change because of this study.

\subsubsection{Previous Experience as a Learner}

Teachers often teach based on their personal theories of teaching that are largely influenced by experiences when they were students (Lortie, 1975). Masako's described her previous experiences as a learner at high school and university:

No English teacher used English in my school days. What I remember is that both teachers and students didn't use English (laughter). I don't think I experienced something memorable as a learner. We were always working on exercise books. We finished using the textbook in the $2^{\text {nd }}$ grade of high school and at the third grade we were working on an exercise book for entrance exams. ...My major at the university was Swedish, and I learned Swedish in the rote manner. The way we learned Swedish at university was almost the same one [approach] that Japanese teachers taught English at high school in Japan. (INT-1)

Masako's experience as a learner was reflected in her own instruction. Studying a foreign language was built around the textbook and rote learning. This was noted in the following:

She started with greetings and moved on to vocabulary definitions, and had students listen to the $\mathrm{CD}$, repeating after her. Then, a comprehension quiz ( $\mathrm{T}$ or F), followed by grammar explanations with a handout and grammar drills. Finally, a 
quasi-interactive activity. Students were put into pairs and one student read Japanese and the other translated it into English and they switched roles with each paragraph. There was little room for students to use English communicatively. The English used most frequently by Masako was descriptive, classroom management English, such as 'Pass your handout to the front' or 'Look at the blackboard.' (OFN-1)

Later during the stimulated recall session, Masako showed that she was at a rather frozen static state in her development:

I think we have to teach English for having students getting good scores on the tests.

Unless the test changes, how can we teachers change the way of teaching? (SR-1)

One way for teaching approaches to change occurs through pre- and in-service training. Next, Masako revealed her developmental experiences.

\subsubsection{Previous Expertise}

As for teaching language communicatively, Masako clearly pointed out that she lacked knowledge of teaching English for that purpose:

I think I took a course of something related to communicative language teaching in a teacher license course at the university. It must have been needed for a required course, though, I don't remember what we did in the course. Maybe we read some textbook and wrote some report. (INT-1)

In-service training was not helpful either. Earlier Masako taught at a public high school, where officially MEXT-supported teacher development programs had been going on. Masako explained the reason those development programs seemed unsuccessful:

When I was at the workshop operated by the study group of the board of education during summer break, I was exhausted from the schoolwork and did not remember it well. What they spoke about was rather in vague generalities...I am not sure whether I can implement activities or new approaches introduced at the seminar because they don't know our students, they don't know anything about our school. So, when I got back to daily schoolwork, I think I easily got back to my usual teaching approaches. (INT-1)

Masako returned to being in a safe, harmonious, static state. Teachers' beliefs are deeply held, often resistant to change, and heavily influenced by the school culture (Pajares, 1992). In Masako's case, it was because of a mismatch between instruction at workshops about what she ought to do and what she faced in her classrooms.

\subsubsection{Harmony with the Other Teachers}

Another factor for resisting change was to keep harmony with co-workers. The comment below illustrated how Masako avoided causing friction through maintaining harmony with teachers:

I think I have to keep harmony with the other teachers who teach at this grade level. 
We use the same translation handouts at each unit, which was made by the chief teacher for our convenience of not spending much time of preparing each class. (SR-1)

Sharing the same handouts, whether productive or not, was beneficial for keeping a good working relationship with co-workers and saving time and energy, but it could have a negative impact by stifling development (see further below). However, there were indications Masako wanted to make changes in her teaching. These revelations had a positive impact on her instruction as shown in the following.

\subsubsection{Fortuitous Outcomes from Students}

Masako noticed that her lessons provided little flexibility for students to have opportunities to express themselves. One problem was using ready-made handouts from the chief teacher (see above). For example, she distributed a handout with a set of accuracy-focused activities; a list of new vocabularies with translations; true or false questions; detailed grammar explanations under each line; and a list of parallel translations of each sentence:

Yes, it is easy for me to follow the handout and maybe for students as well. But, on the other hand, it is painful to spend more than 15 minutes for vocabulary definitions. Students are deadly quiet, only my voice rings empty. Is it so important to use time for vocabulary definition? (SR-1)

The above suggested an EPD opportunity as Masako was questioning what she was doing and what were the expected outcomes of her students during the lesson. Momentum for change in EPD occurs with awareness of the teaching situation; this can be found in the following comments by Masako, which revealed the potential for teacher development:

However hard I try to explain, students don't pay attention to my explanation and get sleepy. I use prescriptive English such as 'Stand up' 'Open your textbooks' only. Student use English almost zero. No more than 5\%. Only when they do dictation practice in pairs, they have a chance to use English... I know that I have to do something to let students use English in the class. (SR-1)

Masako's observations of a non-interactive classroom atmosphere triggered her desire to create a more interactive teaching and learning atmosphere, which was an impetus for teacher change. A fortuitous outcome emerged during the SR session after she noticed a few students, who were grouped together, had become active:

If I have an idea, I would change the class to be more active. It is really painful for me to see students mentally empty and dying. But students may get active when they are asked to do something different from what they are doing now. The problem is that I don't have a good idea to make a change. (SR-1)

Masako began to question how she could change her instruction to get out of the boredom situation. After noticing that most of the students became a bit more engaged in the group work, she began to think that there must be an effective way to make the students more active. Her interest provided a momentum to eagerly participate in the co-constructed praxis cycles. 


\subsubsection{Willingness to Collaborate to Develop Skills}

A positive sign for getting Masako to implement the new TETE policy was her openness to collaborative development. During an interview session, she remarked:

Again, it is important to think about it [collaborative teacher development]. I found myself to need to know more about teaching. I would like to talk more about teaching with other teachers. We can share our ideas and the realities we are facing, such as students' behavior, teaching and learning. (INT-2)

Teachers need opportunities to interact within a professional dialog so that they can reconstruct better understandings of teaching (Freeman, 1996; Takegami, 2015). John-Steiner and Meehan (2000) wrote, "Teachers, too, need colleagues in the staff room with whom to talk through the various phases of their inquiries" (p.50). These in-depth dialogs to help teachers better conceptualize their practice might be rarely gained at a one-shot workshop as Masako's previous experiences indicated.

The above outcomes were formulated by going through the AR cyclical process, which led Masako to enter a state of change in her teaching. In turn, they were informative to reconstruct her teaching.

\subsection{Masako's Reconstructing Teaching Practice (RTP) Through Praxis}

The data under this category were largely taken from watching videos of Masako's lessons. Opportunities to view the lessons triggered the need to further seek professional knowledge that would guide her to make changes in her teaching, which would also give her students more opportunities to interact in English and increase her own English use.

\subsubsection{Outcomes from Students Trigger Change}

In a stimulated recall session, Masako found that students became engaged in an interactive reading activity that was co-constructed with the author (see Appendix 2). This prompted a decision of an interactive group poster presentation activity using the topic of robot technology in the textbook (see Appendix 3). Following the poster session, Masako noticed positive outcomes from the students:

Please look at this student. [Masako pointed to a student who was interactive both as a presenter and observer.] He used to be very quiet or sleeping during the class, however, he tried to communicate and interact with others. I never imagined that he asked the question such as 'How big is your robot?' 'How can your robot get energy to clean the school yard?' I think that I made new discoveries about students; this is surprising. (SR-5)

Masako's comments revealed a teacher who was starting to see positive changes during the co-construction of her practice. For example, in the poster activity, where students were given a lot of flexibility to produce solutions to a task, she could see how a communicative language teaching approach worked in practice and led to more use of English, including herself: 
While students were presenting the poster, it was interesting to see students used English. Unconsciously, I used English as well. (SR-5)

During the poster presentation, the class became interactive as students communicated in English with each other and with Masako. As Freire (1993, p.92) asserted, "Without dialogue there is no communication, and without communication there can be no true education". Masako could encourage the students by interacting with them in English, which helped to fulfill a principle goal of the TETE policy.

Masako was shifting gradually toward using more English with a student-centered approach. For example, she observed that teaching should go beyond the textbook:

I realize teaching English is not teaching the textbook... nor is teaching English teaching or explaining English. The point is that whether we can teach English through a textbook, like cooking. Whatever great ingredient we have and whatever advanced cooking material we have, it is impossible to cook great meals, if we don't know how to cook and integrate them for making a great meal (Laughter). (SR-5)

Masako's comments show that she could reconceptualize her practice through being involved in on-site collaboration planning of lessons that materialized in practice. Involvement became a powerful aspect of her teacher learning process that was encapsulated in the next subtheme.

\subsubsection{Reconceptualizing Teaching through Co-constructing Lessons}

Working with the author enabled co-constructions of the lessons in a more productive and meaningful way. Masako's progression in the study can be seen in the final AR cycle:

If we [with author] hadn't had any chances to be involved in this practice, I would never develop my most effective teaching style without re-thinking about why I am doing what I am doing. Maybe I would have gone with the flow being dissatisfied with myself. However, what we have done is to make the students active thinkers in the class and to make the students active presenters... Giving students their own responsibility in group work was beyond my idea. Through sharing problems, realities of teaching and students' learning behavior with you [the author], I have come to figure out what I have been doing, and what approach I should take and why. (SR-5)

The adage seeing is believing can be used to explain the cognitive change that was taking place within Masako. The classes were more interactive, a student who normally wouldn't participate did, and her level of expectations of what her students could do rose:

I think we have to trust students. Yes, they can do [it] if we give them the chances to do [it]... 'Trust your students' they can do it. (SR-5)

Masako was shifting gradually toward a student-centered approach. She was getting students as well as herself to actively use the target language. The change in her practice not only created active and productive learning, but also cohered with the TETE policy. 


\section{Discussion}

\subsection{Masako’s Developmental Process}

The first two research questions focused on Masako's perceptions and teaching behaviors within the context of addressing the TETE policy. Through the process of praxis using interventions, Masako became uncomfortable teaching in a static state. Prompted by the author as a MKO, a positive destabilization of her teaching created a momentum for change. The prompting was effective because the author could recognize hotspots, a mismatch or conflict between one's beliefs or intentions and actions (Woods, 1996) that can lead to change. This incited Masako to reconceptualize her instruction and make changes (RTP). Importantly, because of the author's participatory role, the analytical process of this progression could be viewed up close, and this provided the author with rich insights, which helped in the co-constructed lessons during praxis cycles. She could see some of her ideas, accelerated through co-constructive collaborations, come to fruition in practice with the increased activity of students to apply what they were learning in a CLT-oriented poster activity. She entered a RTP stage because she could articulate those ideas through professional discourse (Freeman, 1996).

However, the progression from EPD to RTP categories cannot be cleanly separated. Unlike a cicada, Masako does not simply develop at each stage and shed one skin for another. The realities of these states are much messier and less linear than should be expected. Realities that are fundamental to the Japanese educational context, such as preparing students for exams, saving time, and keeping harmony with what other teachers are doing continue to play a role creating challenges for Masako to resist being in a static teaching state. Like other JTEs, who are in a state of EPD, Masako may still puzzle over how much English to use because of students' proficiency levels and how to get adequate teacher professional development. Nonetheless, engagement in her own teaching had progressed.

\subsection{General Model of Teacher Development Meeting TETE Policy.}

The third research question addressed the outcomes of the study in terms of Masako's teacher development. They emerged in the formation of the thematic categories that represented insightful areas of her developmental process toward meeting the TETE goal. Although outcomes of this case study cannot be generalized, they may have resonance with other JTEs or other teachers working in similar contexts. Based on this caveat, a developmental model is depicted below (see Figure 2).

In the model, curriculum policy reflecting the two policy goals are placed at the top. Positioned immediately below on the left are the on-site, collaborative AR interventions informed by practical applications of professional knowledge (theory and methods). Through on-site collaboration, frictional forces caused by a mismatch of expected policy implementations made at institutional levels and what JTEs are prepared to do in the classroom are revealed. Negative and positive forces of friction recognized as EPD are thus brought to light though on-site teacher development as in this study. When resistance is too strong, movement stops (like hitting a wall). This is the static state. When there is less 
resistance to friction, movement increases. This is viewed as a positive momentum for teacher change. In complexity science, when change introduces too much destabilization to the status quo, it creates chaos, and organisms will highly resist change (Larsen-Freeman, 1997) as represented by the dotted areas. When there is constructive friction, teacher development or implementation of policy can occur as indicated by the solid arrows. On the right, change occurs in a bottom-up direction underpinning the RTP category using Guskey's (2002) seeing is believing claim that a teacher's belief in change must occur with successful implementation in the classroom

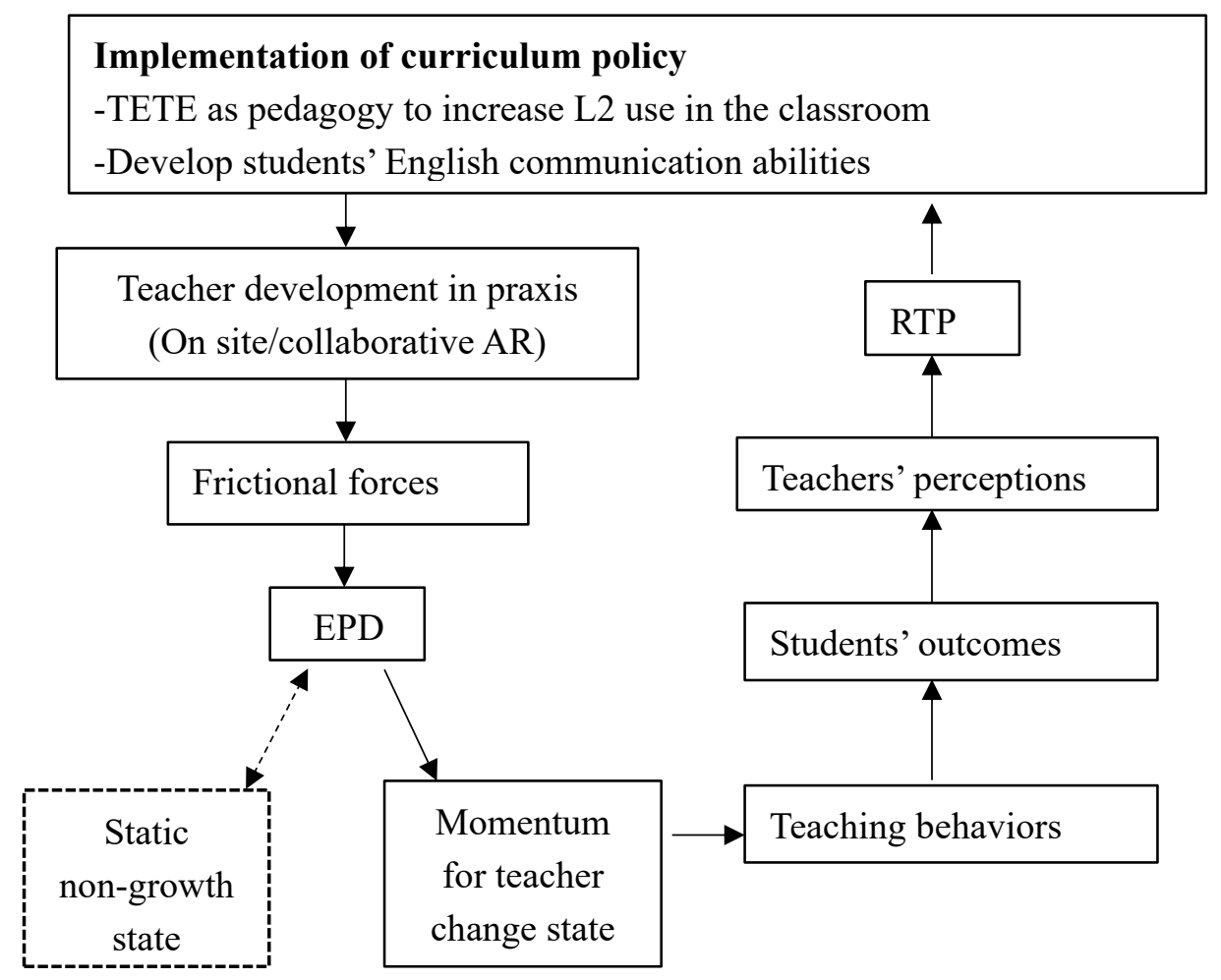

Figure 2. General Model Mapping of JTE Teacher Development Meeting TETE Policy

The model shows a reciprocal and linear flow of teacher learning. These two directions acknowledge the impact of teacher cognition that manifest in the complexities and possibilities of Masako's teacher development. The model also recognizes the importance of on-site collaborative teacher development occurring at local schools with other teachers. If possible, the inclusion of experienced MKOs would add more professional knowledge and perhaps constructive friction by being up close to the process affording opportunities to identify hotspots as the on-site, collaborative design of the study led to depictions of Masako's developmental process.

\section{Conclusion}

By being with the JTE in her work environment, perhaps the most important finding of the 
study was to identify the complexities of teaching that surround Masako with the two core themes. EPD suggested that out of uncertainty and chaos can emerge a productive state of destabilization, which propelled her to change, to evolve. The RTP category illustrated that change needs to be demonstrated in practice. Through the RTP category, the process of praxis focusing on transformative action could be documented suggesting a positive direction toward meeting the TETE policy. Based on the outcomes of this study, a recommendation for teacher development was demonstrated in the proposed model. The realities that were delineated by the core themes that Masako faced in her instruction may resonate with JTEs who are consciously working out how to implement the TETE policy. Therefore, a plausible recommendation is that if JTEs are experiencing similar thought processes, constraints, and desires to make changes in their instruction, then the model's strength can be seen in transferability (Glaser, 1998; Trochim, 2006). This point helps makes the argument for more follow-up studies in teacher development.

\section{References}

Allen, P., Fröhlich, M., \& Spada, N. (1984). The communicative orientation of second language teaching: An observation scheme. In J. Handscombe, R. Orem, \& B. Taylor (Eds.), On TESOL '83, 231-252. Washington, DC: TESOL.

Allwright, D. (1988). Observation in the language classroom. London: Longman.

Bogdan, R. C., \& Biklen, S. K. (1998). Qualitative research in education: An introduction to theory and methods. Sydney: Allyn and Bacon.

Borg, S. (2003). Teacher cognition in language teaching: A review of research on what language teacher think, know, believed and do. Language Teaching, 36(2), 81-109. https://doi.org/10.1017/s0261444803001903

Burns, A. (1992). Teacher beliefs and their influence on classroom practice. Prospect, 7(3), 56-66.

Burns, A. (1999). Collaborative action research for English language teachers. Cambridge: Cambridge University Press.

Clark, C. M., \& Peterson, P. L. (1986). Teachers' thought processes. In M. C. Wittrock (Ed.), Handbook of research on teaching (3rd Ed.), 55-296. New York, NY: Macmillan Publishing Co.

Farrell, T. S. C. (2015). Promoting teacher reflection in second language education: A framework for TESOL Professionals. New York, NY: Routledge.

Freeman, D. (1996). Renaming experience/reconstructing practice: Developing new understanding of teaching. In D. Freeman, \& J.C. Richards (Eds). Teacher learning in language teaching, 221-241. Cambridge: Cambridge University Press.

Freire, P. (1993). Pedagogy of the oppressed. New York, NY: Continuum. 
Glaser, B. G., \& Strauss, A. L. (1967). The discovery of grounded theory: Strategies for qualitative research. Chicago: Aldine.

Glaser, B. (1998). Doing grounded theory: Issues and discussions. Mill Valley, CA: Sociology Press.

Guskey, T. M. (2002). Professional development and teacher change. Teachers and Teaching: Theory and Practice, 8(3/4), 381-391. https://doi.org/10.1080/135406002100000512

Igawa, K. (2013) Language proficiency development needs of NNS English teachers in Japan. Shitennoji University Bulletin, 56, 1-25.

John-Steiner, V. P., \& Meehan, T. M. (2000). Creativity and collaboration in knowledge construction. In C. D. Lee and P. Smagorinsky, (Eds.), Vygotskian perspectives on literacy research: Constructing meaning through collaborative inquiry, 31-50. Cambridge: Cambridge University Press.

Johnson, K. (2006). The Sociocultural turn and its challenges for second language teacher education. TESOL Quarterly, 40(1), 235-257. https://doi.org/10.2307/40264518

Kubanyiova, M., \& Feryok, A. (2015). Language teacher cognition in applied linguistics research: Revisiting the territory, redrawing the boundaries, reclaiming the relevance. The Modern Language Journal, 99(3), 435-449. https://doi.org/10.1111/modl.12239

Kumaravadivelu, B. (2006). Understanding language teaching: From method to postmethod. Mahwah, New Jersey, Lawrence Erlbaum Associates

Larsen-Freeman, D. (1997). Chaos complexity science and second language acquisition. Applied Linguistics, 18(2), 141-165. Oxford University Press.

Lortie, D. (1975). Schoolteacher: A sociological study. Chicago: University of Chicago Press.

MEXT. (2009). Koutougakkou gakushu shidou yoryo gaikokugo eigoban kariyaku [Course of study for foreign languages in senior high schools; provisional version]. Retrieved from www.mext.go.jp/a_menu/shotou/new-cs/ youryou/eiyaku/1298353.htm

Pajares, M. (1992). Teachers' beliefs and educational research: Cleaning up a messy construct. Review of Educational Research, 3, 307-332. https://doi.org/10.3102/00346543062003307

Strauss, A., \& Corbin, J. (1998). Basics of qualitative research. Thousand Oakes, CA: Sage Publications.

Tahira, M. (2012). Behind MEXT's new course of study guidelines. The Language Teacher, 36, 3-9. Retrieved from https://jalt-publications.org/files/pdf-article/36.3_art1.pdf

Takegami, F. (2015). A JTE's conceptualizations of a lesson grounded in professional discourse to better inform practice. The Asian Journal of Applied Linguistics, 2(3), 186-201. 


\section{Macrothink}

Trochim, W. (2006) Qualitative validity. Web Center for Social Research Methods. Retrieved from http://www.socialresearchmethods.net/kb/qualval.php

Tsukamoto, M., \& Tsujioka, N. (2013). Teaching English through English to senior high school students in Japan: Towards the implementation of the new course of study. The Bulletin of Shitennoji University, 55, 309-324.

Vygotsky, L. (1933/1978). The mind in society. Cambridge, MA: Harvard University Press. (Original work published 1938)

Wallace, M. (1998). Action research for language teachers. Cambridge: Cambridge University Press.

Woods, D. (1996). Teacher cognition in language teaching. Cambridge: Cambridge University Press.

\section{Glossary}

JTE: Japanese teacher of English

TETE: teaching English through English

AR: action research

EPD: existing positive disharmony

RTP: reconstructing teaching practice 


\section{Appendices}

Appendix1. Masako's Praxis in Teacher Development AR Cycles

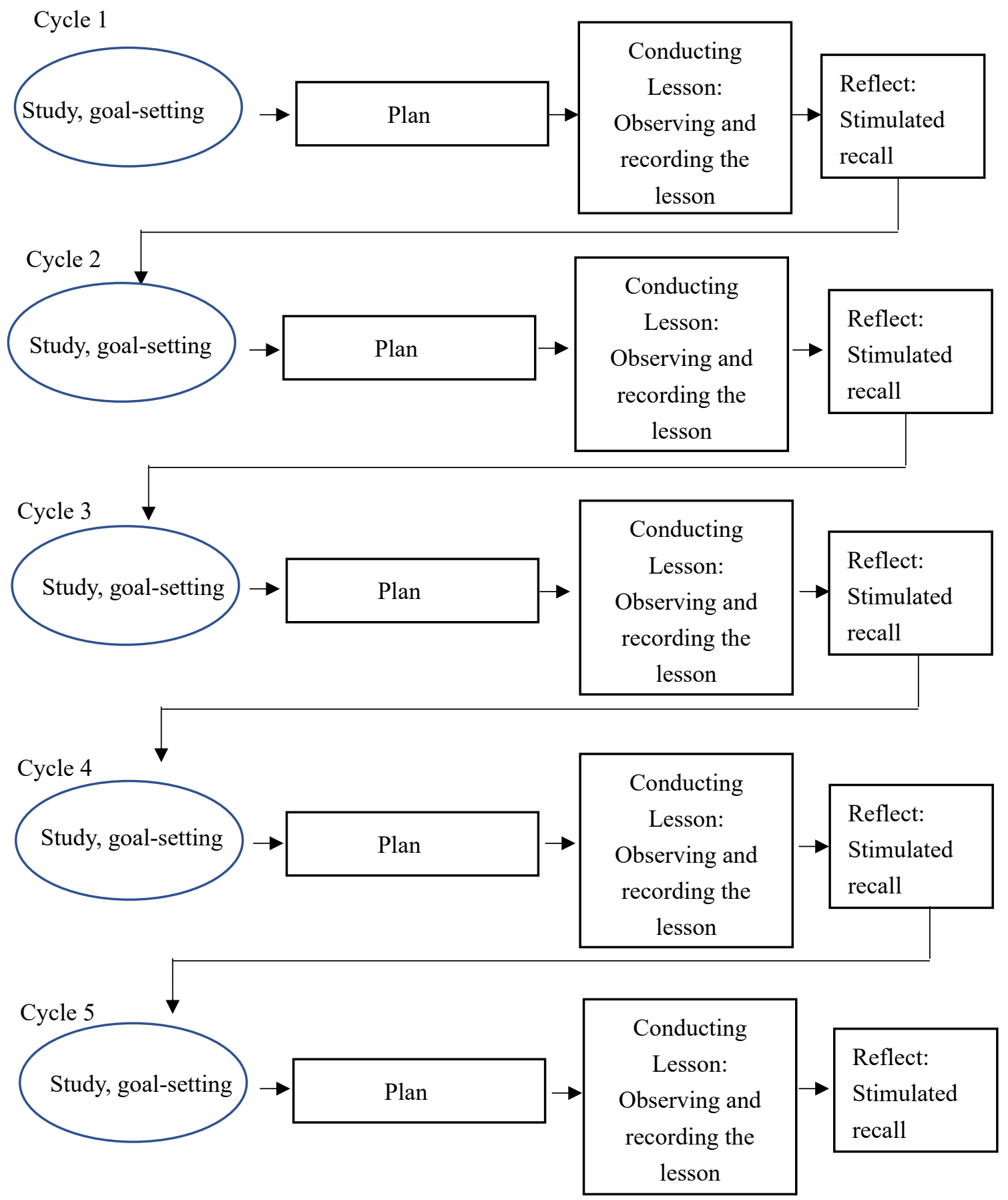


Appendix 2. Masako's Co-constructed Lesson Planning through AR Cycles

\begin{tabular}{|c|c|c|c|c|}
\hline $\begin{array}{c}\text { AR } \\
\text { stage }\end{array}$ & urpose & Activity & $\begin{array}{c}\text { Expected Ss. } \\
\text { outcome }\end{array}$ & $\begin{array}{l}\text { Masako's ideas } \\
\text { integrated in plan }\end{array}$ \\
\hline $1^{\text {st }}$ & $\begin{array}{l}\text {-PK (professional } \\
\text { knowledge) addressed } \\
\text { regarding CLT } \\
\text { approach to meet } \\
\text { collaborative goals: } \\
\text {-Have students (Ss.) } \\
\text { use L2 and learn } \\
\text { through collaborative } \\
\text { activity. } \\
\text {-Have Ss come to } \\
\text { understand targeted } \\
\text { vocabulary and } \\
\text { grammar working } \\
\text { collaboratively. }\end{array}$ & $\begin{array}{l}\text {-Vocabulary } \\
\text { activity } \\
\text { embedded in } \\
\text { CLT. } \\
\text {-Reading } \\
\text { activity } \\
\text { embedded in } \\
\text { CLT. (have Ss } \\
\text { make questions } \\
\text { in the group and } \\
\text { interact in } \\
\text { English) }\end{array}$ & $\begin{array}{l}\text {-More English } \\
\text { from Ss is } \\
\text { expected through } \\
\text { collaborative } \\
\text { language } \\
\text { learning. } \\
\text {-Ss will not be } \\
\text { comfortable so } \\
\text { much with } \\
\text { English use. }\end{array}$ & $\begin{array}{l}\text {-Change } \\
\text { pairs/groups: Ss. } \\
\text { rotate and interact } \\
\text { more. } \\
\text {-Create activity to } \\
\text { avoid boredom of } \\
\text { Masako's } \\
\text { explanations longer } \\
\text { than } 5 \text { minutes. } \\
\text {-Choose } \\
\text { challenging } \\
\text { questions and have } \\
\text { Ss. figure out and } \\
\text { present ideas. }\end{array}$ \\
\hline $2^{\text {nd }}$ & $\begin{array}{l}\text {-PK addressed: } \\
\text {-Have Ss. grasp the } \\
\text { content \& summarize } \\
\text { it working together. } \\
\text {-Have Ss. notice \& } \\
\text { reflect on their errors. } \\
\text {-Give Ss chances to } \\
\text { use English. }\end{array}$ & $\begin{array}{l}\text {-Reading } \\
\text { activity with } \\
\text { making a } \\
\text { summary and } \\
\text { have Ss. present } \\
\text { their summary in } \\
\text { English. }\end{array}$ & $\begin{array}{l}\text {-Engage with } \\
\text { classmates } \\
\text { through error } \\
\text { correction. } \\
\text {-Gradual critical } \\
\text { thinking } \\
\text { development. }\end{array}$ & $\begin{array}{l}\text {-Error correction } \\
\text {-Make corrections } \\
\text { of errors and have } \\
\text { Ss. involved the } \\
\text { finding mistakes. }\end{array}$ \\
\hline $3^{\text {rd }}$ & $\begin{array}{l}\text {-PK addressed } \\
\text {-Have Ss. relate to the } \\
\text { reading material. } \\
\text {-Have Ss. use } \\
\text { grammar points in } \\
\text { mini presentation. } \\
\text {-Give Ss. more } \\
\text { chances to share their } \\
\text { own ideas in English. }\end{array}$ & $\begin{array}{l}\text { - Ss. write their } \\
\text { own ideas on the } \\
\text { topic and have } \\
\text { them present in } \\
\text { the rotating } \\
\text { manner. }\end{array}$ & $\begin{array}{l}\text {-Sentence level } \\
\text { English above } \\
\text { one word } \\
\text { utterances. } \\
\text {-Present Ss.' own } \\
\text { ideas clearly and } \\
\text { listen to others. }\end{array}$ & $\begin{array}{l}\text {-Change groups to } \\
\text { have Ss. } \\
\text { communicate with } \\
\text { different partners } \\
\text { and groups. }\end{array}$ \\
\hline $4^{\text {th }}$ & $\begin{array}{l}\text {-PK addressed } \\
\text {-Have Ss. improve on } \\
\text { the sense of group } \\
\text { accountability. } \\
\text {-Have Ss. reflect on } \\
\text { what they learned from } \\
\text { reading material. } \\
\text {-Have Ss. practice } \\
\text { English. }\end{array}$ & $\begin{array}{l}\text {-Poster } \\
\text { preparations } \\
\text {-in a group of } 4 \text {, } \\
\text { Ss. make the } \\
\text { poster about the } \\
\text { robot. } \\
\text { - Prepare the } \\
\text { script for the } \\
\text { presentation. }\end{array}$ & $\begin{array}{l}\text {-Attitude to help } \\
\text { each other in } \\
\text { poster making } \\
\text { projects. } \\
\text {-More English } \\
\text { and not } \\
\text { incomplete } \\
\text { sentences. }\end{array}$ & $\begin{array}{l}\text { - Put active Ss. as } \\
\text { leaders of each } \\
\text { group to promote } \\
\text { group work. }\end{array}$ \\
\hline $5^{\text {th }}$ & $\begin{array}{l}\text {-PK addressed } \\
\text {-To have Ss. meet } \\
\text { challenges of making } \\
\text { poster presentations. } \\
\text {-To have Ss. improve } \\
\text { communication skills } \\
\text { through interaction in } \\
\text { poster presentations. }\end{array}$ & $\begin{array}{l}\text {-Poster } \\
\text { presentations }\end{array}$ & $\begin{array}{l}\text { *Unexpected } \\
\text { active English use } \\
\text { in Q \& A poster } \\
\text { session } \\
\text { - Focus more on } \\
\text { fluency English: } \\
\text { incomplete } \\
\text { sentences are OK. }\end{array}$ & $\begin{array}{l}\text {-Have the Ss. } \\
\text { evaluating } \\
\text { presentations. } \\
\text {-Organize the } \\
\text { formation of } \\
\text { presentation. } \\
\text {-Prepare the } \\
\text { evaluation sheet. }\end{array}$ \\
\hline
\end{tabular}


Appendix3. Notable Points of Each Intervention in AR Cycles

\section{$1^{\text {st }}$ intervention}

Vocabulary definition is to be minimized in the pair work: student A read the definition of vocabulary in English (e.g., 'The definition of this vocabulary is .....' 'What do you think this vocabulary is?') and student B answers with the vocabulary without looking at the handout. If student $\mathrm{B}$ wants student $\mathrm{A}$ to repeat the vocabulary, then students are expected to use the confirmation phrases in English written on the board for help in their understanding and interact with each other.

Then, the next step is to have students read the sentences paragraph by paragraph in turn in pairs and switch parts by having them use those communication strategy confirmation phrases on the board, which is to create more English use. The first pair was in horizontal rows and the next pair was in tandem rows. In this way students may have chances to read and listen to the whole section.

Instead of having students working individually, the next step is to have students create five comprehension questions and prepare answers for 10 minutes in pairs and then they ask their questions to another pair. Masako has to work as a facilitator while students are making questions walking among the students' desk with checking, encouraging and occasionally checking their grammatical mistakes.

It was decided that Masako could conclude the lesson by choosing some good questions, have them present and have all students involved in the activity.

\section{$2^{\text {nd }}$ intervention}

In this intervention, one more activity, 'summarization', was added on Masako's request. Before moving to the summarization, we needed to correct some errors of students' question forms from the $1^{\text {st }}$ intervention. Masako corrected the handout and took the copies of their writing and picked up some of them and printed them out to make the error corrections. Based on the principles of CLT and TETE policy, the goal of the class was focused on more of a student-centered approach, which would leave her more chances to use English and students as well. Followed by error correction from the previous class, the class would go on reading the next section in pairs with encouraging students using the confirmation phrases and vocabulary definitions. At the stage of the planning, the goal of the class and expected students' outcome was examined as well. We went back and forth between the textbook, the CLT definitions and lesson plan list (from Lewis and Hurd, 2011) several times to decide the lesson.

The lesson is focused on the summarization of the reading material to have students grasp the overview of the content. Students in pairs work on summarization with the hint of the key words and key expressions to make their work smoother and better. Masako works as a facilitator, checking students' writing and asking questions to see that their work goes smoothly.

Since they finished the reading section 1 and 2 so far, Masako decided to conduct the class in 


\section{Macrothink

the similar way for the next two sections of 3 and 4. My suggestion was that students would choose four presenters of their summarization from the group of eight, where four students can be chosen from a pair.

\section{$3^{\text {rd }}$ intervention}

At the end of the reading class, we decided to challenge the students more by making mini presentations. In order to stimulate their critical thinking along with the purpose of the reading material and using grammar point, students are expected to write their own ideas of "What is happening every 20 minutes in the world?" aiming to have students connect to the reading material. Then, present in the group and pick the best one in the group and present to the class.

\section{$4^{\text {th }}$ intervention}

At the conclusion of the reading unit, it was decided to do presentations as MEXT's English reform plan suggests. Since Masako did not have any idea about how to provide students with directions of the procedures, we spent rather much time to establish the procedures. The aim was to bring students' creativity together by having students work collaboratively and critically.

The title was 'Robot' along with the content of the reading unit. Since Masako mentioned that the content of the textbook was not related to the students' real life, we decided to have students in the group of four create a robot to promote.

A group of four students need to decide the name of the promotion company, and each student had a role to present their robot, such as a mechanic, a designer so on. A3 size paper is distributed to each group to draw the image of the robot and make the script for presentation. Students in the group make their scripts to get attention from viewers. Each student should make her/his own script respectively, and has a responsibility to present her/ his role and answer and defend it.

\section{$5^{\text {th }}$ intervention}

In poster presentations, regarding Masako's interest to conduct lesson with more English, students are given guidelines of English phrases to use to increase target language use for making presentations as follows: 


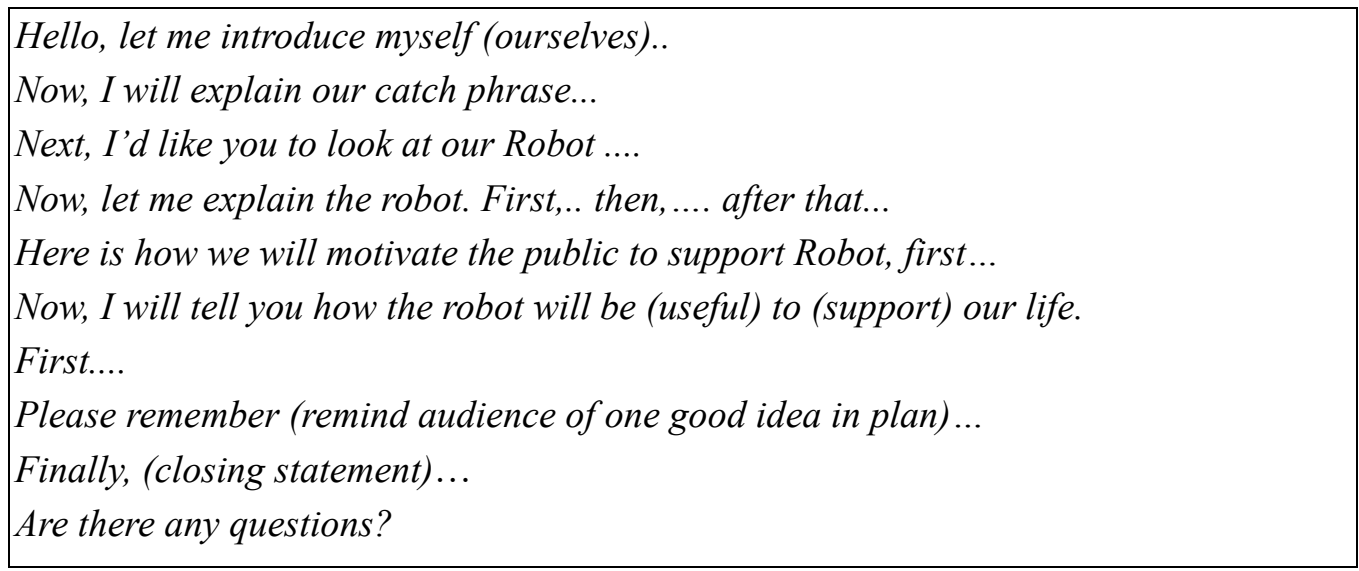

Before starting presentations, students have chances to practice. They are told to think about eye contact, gestures and voice intonation for smooth delivery. The teacher goes around to groups reminding them that they are expected to practice English as fluently as possible without reading their script. Their posters are displayed in four areas of the classroom and the first four groups start to present their projects. The other groups who present later, form the role of rotating viewers. As the class is divided into two big groups of 16, each group of four members has four chances to present to each rotating group. Question and answer sessions between viewers and presenters are in English and evaluations were carried out through viewing students and teacher. In this way, the presenters have four chances of speaking English and communicating to four different viewer group.

\section{Copyright Disclaimer}

Copyright for this article is retained by the author(s), with first publication rights granted to the journal.

This is an open-access article distributed under the terms and conditions of the Creative Commons Attribution license (http://creativecommons.org/licenses/by/3.0/). 